\title{
Anticoccidial effect of Origanum majoranum aqueous extract on Eimeria tenella-infected chicken
}

\author{
Mohamed, E.R.A. ${ }^{1}$, Elazab, M.F. ${ }^{1 *}$, El-Habashi, N. ${ }^{2}$, Elhawary, N. ${ }^{3}$, Mokhbatly, A.A. ${ }^{1}$ \\ ${ }^{1}$ Clinical Pathology Department, Faculty of Veterinary Medicine, Kafrelsheikh University, 33516, Kafrelsheikh, Egypt \\ ${ }^{2}$ Pathology Department, Faculty of Veterinary Medicine, Kafrelsheikh University, 33516, Kafrelsheikh, Egypt \\ ${ }^{3}$ Parasitology Department, Faculty of Veterinary Medicine, Kafrelsheikh University, 33516, Kafrelsheikh, Egypt \\ *Corresponding author: moh_ot2004@yahoo.com
}

\section{ARTICLE HISTORY}

Received: 27 August 2020 Revised: 27 November 2020

Accepted: 29 November 2020

Published: 25 March 2021

\begin{abstract}
Avian coccidiosis, an important protozoal disease of chicken triggered by coccidian protozoa of genus Eimeria, causes considerable economic losses to broiler producers. The study was designed to assess the efficiency of Origanum majoranum aqueous extract (OMAE) on $E$. tenella-infected broiler chicken. Birds were divided into four groups including: positive control (PC, challenged with $5 \times 10^{4}$ sporulated oocysts of $E$. tenella at the $12^{\text {th }}$ day of age), PC+OMAE (challenged with E. tenella oocysts at the $12^{\text {th }}$ day of age and received OMAE $(125 \mathrm{mg} / \mathrm{kg} \mathrm{BW})$ orally, started at the $7^{\text {th }}$ day of age, and continued for 14 consecutive days), OMAE (received OMAE (125 mg/kg BW) orally, at the $7^{\text {th }}$ day of age, for 14 consecutive days), and negative control (received basal diet only). Anticoccidial efficacy of OMAE was evaluated by complete blood picture, serum chemistry, serum protein electrophoresis, antioxidants markers, cecal oocysts count, and cecal lesions score. Briefly, collected data indicated that supplementation of OMAE could increase antioxidants concentrations and improve changes in hematobiochemical parameters and serum protein fractions, as well as decrease cecal oocysts count and reduce cecal lesion scores in $E$. tenella-infected birds. In conclusion, OMAE restores oxidant-antioxidant balance, and its supplementation in broiler chicken can alleviate $E$. tenella-infection and reduce its severity.
\end{abstract}

Keywords: Origanum majoranum, aqueous extract, Eimeria tenella, chicken.

\section{INTRODUCTION}

Avian coccidiosis, a disease of great economic importance in poultry industry, caused by the intra-cellular protozoan of genus Eimeria. Annually, coccidiosis costs poultry producers at least 2-3 billion US dollars worldwide, including poor growth performance, replacement of chicks, and medication (Dalloul \& Lillehoj, 2006; Quiroz-Castañeda \& DantánGonzález, 2015). In Egypt, the total financial cost of coccidiosis (control, mortality and morbidity) in 2016 was f105.13 million (Blake et al., 2020). Gut protozoan of the genus Eimeria multiplies in the intestinal tract and causes severe intestinal epithelial damage, resulting in the interruption of feeding, digestive processes, nutrient absorption, reduced weight gain, hemorrhage, and promote establishment and growth of potentially pathogenic bacteria (Ritzi et al., 2014; Chen et al., 2020). It has been shown that 9 species of Eimeria occurred in chicken (Joyner \& Long, 1974). E. tenella specifically infect the ceca in chicken (Zhou et al., 2020). E. tenella infection is followed by bloody diarrhea, reduced weight gain, high morbidity, mortality and cecal lesions (petechiae, thickening, ecchymosis, accumulation of bloody caseous material in the cecum) (Jordan et al., 2011; Macdonald et al., 2019). For long time, Eimeria infections have been controlled using anticoccidial drugs, but, extensive and continuing usage of such drugs has led to worldwide progress of drug resistance and the public is becoming more conscious for the harmful effects of drug remains in poultry products (Peek \& Landman, 2011). Also, vaccination is applied in poultry industry as an alternative strategy for prevention and controlling Eimeria infections in broiler chicken. However, several shortcomings of Eimeria spp. vaccines were observed including: increased cost; tendency of losing their immunogenicity with prolonged storage periods, increased susceptibility to bacterial enteritis; challenges with consistent application; and slow development of immunity (Barbour et al., 2015; Kadykalo et al., 2018). Therefore, assessment of new natural medicinal products as an alternative way to control avian coccidiosis is required.

Origanum majorana (OM) L. from the family Lamiaceae (syn. Majorana hortensis Moench) is commonly known as sweet marjoram (Bina \& Rahimi, 2017). Sweet marjoram, popular culinary herbs in the world, was grown in Egypt over 3000 years ago and Egypt produces $90 \%$ of the world's resource (Ramadan et al.., 2013). Also, OM essential oil was used for flavoring sausages, sauces, soups and condiments (Chishti 
et al., 2013). Early, OM has been used by folk medicine for prophylaxis and therapy. The medicinal effects of OM include: a spasmolytic, anti-rheumatic, diuretic, anti-asthmatic antiseptic, carminative, stimulant, and expectorant (Kumar et al., 2011). Furthermore, several reports have shown that OM possess a wide diversity of biological activities, including antioxidant and antibacterial, as well as antifungal, antiprotozoal and hypoglycemic (Prerna \& Vasudeva, 2015). Moreover, OM can be used as potential source of natural antioxidant agents for preventing infections associated with free radicals overproduction (Deuschle et al., 2018). In addition, Origanum aqueous extract ( $A E)$ was shown to have a remarkable capacity in retards lipid oxidation, due to the high content of phenolic compounds and flavonoids (Triantaphyllou et al., 2001). Egyptian OMAE is rich in total phenolic components and flavonoids than the ethanolic ones and showed better antioxidant, anti-microbial and antineurodegenerative activity (Duletić et al., 2018). Besides, Egyptian OMAE exhibited stronger antioxidant properties because of their hydrogen donating abilities and the total scavenging capacities (Vági et al., 2005). Hence, the present experiment assessed the potential antioxidant efficacy of Egyptian OMAE in alleviating the oxidative-inflammatory effect of $E$. tenella infection in broiler chicken.

\section{MATERIALS AND METHODS}

\section{Chicken}

A total of eighty, one-day-aged broiler chicks (Cobb) were purchased from a commercial hatchery, Kafrelsheikh, Egypt. Chicks were housed in experimental room with first temperature fixed at $34^{\circ} \mathrm{C}$ then gradually decreased during the first 3 weeks of life to $25^{\circ} \mathrm{C}$. Feed and water were supplied ad libitum. Chick's related procedures were approved according to appropriate methods, and an approval was obtained from the ethical committee of Kafrelsheikh University (KFS-2018/2).

\section{Preparation of OM extract}

Origanum majoranum plant material was acquired from a local herbal-specialized company (Cairo, Egypt) and identified in Zoology Department, Faculty of Science, and Kafrelsheikh University. The fresh OM leaves were air-dried in the shade and coarsely powdered at ambient temperature. Extracts of air-dried plant materials were prepared by using water as solvent. Hot AE was prepared by boiling $500 \mathrm{gm}$ of dried plant material from OM in $5 \mathrm{~L}$ distilled water for $3 \mathrm{~h}$ then left to cool at room temperature and filtered using double layers of gauze. Extracts were concentrated by rotational evaporation. The extraction yield was $6.3 \%$. Dried extracts (green residue) were weighed and stored in a refrigerator at $4^{\circ} \mathrm{C}$ until use.

\section{Experimental design}

Chicks were arbitrarily divided into 4 groups. Each group were subdivided into four replicates (5 birds/each) and received one of four treatments: (1) chicks fed basal diets and challenged with $5 \times 10^{4}$ oocysts of E. tenella at the $12^{\text {th }}$ day of age (positive control, PC); (2) chicks fed basal diets and received OMAE at the $7^{\text {th }}$ day of age, for 14 consecutive days then challenged with $E$. tenella oocysts at the $12^{\text {th }}$ day of age (PC+OMAE); (3) chicks fed basal diets and received OMAE at a dose of $125 \mathrm{mg} / \mathrm{kg} \mathrm{BW} /$ day, orally, started at the $7^{\text {th }}$ day of age, and continued for 14 consecutive days (OMAE); (4) chicks fed basal diets only (negative control, NC). The administration period of OMAE started from the $7^{\text {th }}$ to $21^{\text {st }}$ days of age. The optimal dose of OMAE was carefully chosen according to Al-Harbi (2011).

\section{Parasite collection and challenge}

E. tenella oocysts were collected from the cecum of naturally diseased chicken. Infected chicken were collected from commercial local farms. Collected oocysts were washed and concentrated by using floatation technique using saturated sodium chloride solution. Sporulation of oocysts was done in a moist chamber at $24-26^{\circ} \mathrm{C}$. Sporulated oocysts were stored in $2.5 \%$ potassium dichromate solution in a refrigerator at $4^{\circ} \mathrm{C}$ until use. At 12 days of age, broiler chicks in PC groups were challenged with sporulated oocysts of E. tenella $\left(5 \times 10^{4}\right.$ oocysts in $1 \mathrm{~mL}$ physiological saline per chick) by oral route of administration.

\section{Counting of oocysts}

Oocysts count was measured in cecal contents collected daily from each replicate, daily from 6 to 9 days post infection (p.i.). Cecal contents were thoroughly mixed in plastic bottles before examination. Counting was performed through using modified McMaster's technique (Coles et al., 1992) and presented as the number of oocysts per gram cecal content.

\section{Blood collection}

Blood samples were obtained 6 days p.i. from each replicate. The withdrawal of blood samples was done from the wing veins of all chicken using disposable syringes and $25 \mathrm{G}$ needles. Approximately $5 \mathrm{~mL}$ of blood were collected per chicken. Blood sample was divided into two parts. The first part $(1 \mathrm{~mL})$ was placed into sterile glass tubes with anticoagulant for hematological analysis. The second part was placed into sterile glass tubes without anticoagulant for separation of serum. Serum was separated by centrifugation at $3,000 \mathrm{rpm}$ for 15 minutes and stored at $-20^{\circ} \mathrm{C}$ until use.

\section{Hematological examination}

The erythrocyte and leukocyte counts were measured with a Neubauer hemacytometer slide using the Natt-Herrick solution as diluent stain (Natt \& Herrick, 1952). The hemoglobin $(\mathrm{Hb})$ concentration was measured by cyanomethahemoglobin method using a commercial kit and before reading the absorbance, $\mathrm{Hb}$ test samples were centrifuged to remove dispersed nuclear material. Packed cell volume (PCV) was measured by microhematocrit centrifugation technique $(10,500 \times \mathrm{g}$ for $5 \mathrm{~min})$ and a micro-capillary reader (Coles, 1986). RBC indices (mean corpuscular volume, mean corpuscular hemoglobin and mean corpuscular hemoglobin concentration, $\mathrm{MCV}, \mathrm{MCH}$ and $\mathrm{MCHC}$, respectively) were mathematically calculated using standard formulas according to Greer et al. (2014). Blood smears were stained by Diff-Quik stain for differential leukocyte count.

\section{Biochemical measurements}

Serum activities of aspartate transaminase (AST), alanine transaminase (ALT), gamma glutamyle transferase (GGT), alkaline phosphatase (ALP), and lactate dehydrogenase (LDH) as well as serum concentrations of total protein, triglycerides, total cholesterol, high density lipoproteins (HDL), low density lipoproteins (LDL), glucose, and uric acid were determined by using an automatic chemical analyzer (Cobas 8000, Roche, Germany).

\section{Serum protein electrophoresis}

Total serum protein concentration was evaluated calorimetrically, and then serum protein was fractionated by electrophoresis on cellulose acetate in a Serum Electrophoresis Automated System (Minilite, Cell Diagnostic Division, Italy) according to the procedure described by the manufacturer. Five protein fractions (albumins, $\alpha_{1}$-globulins, $\alpha_{2}$-globulins, $\beta$-globulins, and $\gamma$-globulins) were identified 
and assessed in all serum samples. Absolute values for each fraction were mathematically obtained by multiplying percentage by total protein concentration. The albumin/ globulin $(A / G)$ ratios were calculated by dividing albumin concentrations by the sum of globulins concentrations individually.

\section{Measurement of antioxidant markers}

Reduced glutathione (GSH), superoxide dismutase (SOD), and catalase (CAT) were measured in cecal tissues by spectrophotometric methods according to Beutler et al. (1963), Paoletti and Mocali, (1990) and Sinha (1972), respectively.

\section{Necropsy and histopathology}

After blood collection, chicken were slaughtered and intestine was removed and opened. Sections of the intestine at the level of the cecum and colon were fixed immediately in $10 \%$ formalin and were processed for histopathological evaluation using routine paraffin embedding method. Sections of $3 \mu \mathrm{m}$ thickness were cut and stained using hematoxylin and eosin (HE) for light microscopic examination as mentioned by Bancroft and Gamble (2007). Histomorphology of cecum and colon at the day $6^{\text {th }}$ post infection with $E$. tenella representing scores (Table 4). Inflammatory cells infiltrations (severity and extent), epithelial changes (erosion) and mucosal architecture (ulceration) and the parasitic load were evaluated according to scoring scheme with little modifications (Erben et al. 2014). A. Sum score 1: minimal mucosal inflammatory cell infiltrates with intact epithelium with minimal parasitic load; B. Sum score 2: mild inflammatory cell infiltrates into mucosa and submucosa with focal erosion and mild parasitic load; C. Sum score 3: moderate mucosal and submucosal infiltrates with focal ulceration and moderate parasitic load; D. Sum score 4: marked inflammatory cell infiltrates in mucosa and submucosa and focal ulceration with marked parasitic load; E. Sum score 5: marked inflammatory cell infiltration into mucosa, submucosa and transmural with extensive ulcerations with marked parasitic load.

\section{Statistical analysis}

Data were statistically analyzed using a statistical software program (SPSS 17.01 for Windows, SPSS Inc., USA). Groups's data were compared by one-way analysis of variance, followed by Duncan test. Data of each study group were expressed as means \pm SD and $P<0.05$ was considered as statistically significant.

\section{RESULTS}

\section{Hematology}

Erythrogram's data obtained from the present study revealed significant decreases in mean values of erythrocyte counts, $\mathrm{Hb}$ concentration, $\mathrm{PCV}$ percentage and $\mathrm{MCHC}$ in $\mathrm{PC}$ group compared to NC group (Table $1 ; P<0.05$ ). However, $\mathrm{PC}+\mathrm{OMAE}$ group showed non-significant differences compared to NC group (Table $1 ; P>0.05$ ). Also, leukogram data revealed significant leukocytosis, heterophilia, and monocytosis in PC group compared to NC group (Table $1 ; P<0.05$ ). Moreover, non-significant lymphocytopenia was observed in $P C$ group compared to NC group (Table 1; $P>0.05$ ). However, $\mathrm{PC}+\mathrm{OMAE}$ group showed significant leukocytosis and heterophilia only compared to NC group (Table $1 ; P<0.05$ ). Although, the total leukocyte and heterophil counts were significantly lower in $P C+O M A E$ group compared to $P C$ group (Table $1 ; P<0.05$ ). Furthermore, heterophil/lymphocyte ratios were significantly increased in PC group compared to NC group (Table 1; $P<$ 0.05 ), but $\mathrm{H} / \mathrm{L}$ ratios of $\mathrm{PC}+\mathrm{OMAE}$ group showed non-significant differences when compared to NC group (Table $1 ; P>0.05$ ).

\section{Biochemistry}

The enzymes profile was included AST, ALT, GGT, ALP, and LDH. Serum bioactivities of AST, ALT, GGT, and LDH in all groups showed non-significant differences between all groups (Table 2; $P>0.05$ ). Serum bioactivities of ALP in PC group showed significant decreases compared to NC group (Table 2; $P<0.05)$. However, serum bioactivities of ALP in PC+OMAE group showed non-significant differences compared to NC group (Table 2; $P>0.05$ ). Furthermore, lipid profile was included triglycerides, cholesterol, HDL and LDL. The concentrations of triglycerides, cholesterol and $\mathrm{HDL}$ were significantly decreased in serum samples of PC+OMAE group compared to NC group (Table 2; $P<0.05$ ), but concentrations of LDL were significantly increased in their serums compared to NC group (Table 2; $P<0.05$ ). Also, the serum concentrations of total cholesterol and $\mathrm{HDL}$ in $\mathrm{PC}+\mathrm{OMAE}$ group were significantly decreased compared to NC groups (Table $2 ; P<$ $0.05)$, although their concentrations showed significant

Table 1. Effect of OMAE on blood picture of broiler chicken challenged with sporulated oocysts of E. tenella

\begin{tabular}{|c|c|c|c|c|}
\hline \multirow{2}{*}{ Parameters } & \multicolumn{2}{|c|}{ Control groups } & \multicolumn{2}{|c|}{ Challenged groups } \\
\hline & NC & OMAE & PC & $\mathrm{PC}+\mathrm{OMAE}$ \\
\hline \multicolumn{5}{|l|}{ Erythrogam } \\
\hline $\operatorname{RBCs}\left(\times 10^{6} / \mu \mathrm{l}\right)$ & $2.08 \pm 0.17^{\mathrm{a}}$ & $2.14 \pm 0.19^{a}$ & $1.79 \pm 0.09^{b}$ & $1.94 \pm 0.13^{\mathrm{ab}}$ \\
\hline $\mathrm{Hb}(\mathrm{gm} / \mathrm{dl})$ & $5.34 \pm 0.38^{\mathrm{a}}$ & $5.33 \pm 0.43^{\mathrm{a}}$ & $4.38 \pm 0.47^{b}$ & $4.81 \pm 0.39^{\mathrm{ab}}$ \\
\hline PCV (\%) & $30.00 \pm 0.81^{\mathrm{a}}$ & $30.00 \pm 1.63^{\mathrm{a}}$ & $27.00 \pm 1.41^{b}$ & $28.25 \pm 1.26^{\mathrm{ab}}$ \\
\hline $\operatorname{MCV}(f l)$ & $144.69 \pm 7.79^{a b}$ & $140.74 \pm 6.14^{b}$ & $154.52 \pm 3.42^{\mathrm{a}}$ & $145.68 \pm 6.33^{\mathrm{ab}}$ \\
\hline $\mathrm{MCH}(\mathrm{pg})$ & $25.68 \pm 0.44^{a}$ & $24.95 \pm 0.80^{\mathrm{a}}$ & $25.03 \pm 1.66^{\mathrm{a}}$ & $24.79 \pm 1.61^{\mathrm{a}}$ \\
\hline $\mathrm{MCHC}(\mathrm{gm} / \mathrm{dl})$ & $17.78 \pm 0.80^{\mathrm{a}}$ & $17.74 \pm 0.52^{\mathrm{a}}$ & $16.21 \pm 1.23^{b}$ & $17.02 \pm 0.76^{\mathrm{ab}}$ \\
\hline \multicolumn{5}{|l|}{ Leukogram } \\
\hline $\operatorname{TLC}\left(\times 10^{3} / \mu \mathrm{l}\right)$ & $15.50 \pm 0.65^{c}$ & $16.25 \pm 0.35^{b c}$ & $20.40 \pm 0.96^{\mathrm{a}}$ & $17.21 \pm 0.65^{b}$ \\
\hline Heterophils $\left(\times 10^{3} / \mu \mathrm{l}\right)$ & $5.11 \pm 0.17^{c}$ & $5.33 \pm 0.33^{\mathrm{bc}}$ & $9.08 \pm 0.44^{\mathrm{a}}$ & $5.90 \pm 0.64^{b}$ \\
\hline Lymphocytes $\left(\times 10^{3} / \mu \mathrm{l}\right)$ & $9.34 \pm 0.54^{\mathrm{ab}}$ & $9.95 \pm 0.43^{a}$ & $8.76 \pm 0.22^{b}$ & $9.89 \pm 0.52^{\mathrm{a}}$ \\
\hline Monocytes $\left(\times 10^{3} / \mu \mathrm{l}\right)$ & $0.74 \pm 0.24^{b c}$ & $0.65 \pm 0.23^{c}$ & $2.20 \pm 0.29^{a}$ & $1.08 \pm 0.24^{b}$ \\
\hline Eosinophils $\left(\times 10^{3} / \mu \mathrm{l}\right)$ & $0.31 \pm 0.14^{\mathrm{a}}$ & $0.33 \pm 0.13^{a}$ & $0.36 \pm 0.11^{\mathrm{a}}$ & $0.35 \pm 0.21^{\mathrm{a}}$ \\
\hline $\mathrm{H} / \mathrm{L}$ ratio & $0.55 \pm 0.03^{b}$ & $0.54 \pm 0.04^{b}$ & $1.04 \pm 0.04^{a}$ & $0.60 \pm 0.10^{b}$ \\
\hline
\end{tabular}

Data of each group were expressed as means \pm SD. Mean values in the same row bearing different superscript letters were significantly differ at $(P$ $<0.05)$. 
Table 2. Effect of OMAE on serum chemistry, protein fractions and antioxidant markers in broiler chicken challenged with sporulated oocysts of E. tenella

\begin{tabular}{|c|c|c|c|c|}
\hline \multirow{2}{*}{ Parameters } & \multicolumn{2}{|c|}{ Control groups } & \multicolumn{2}{|c|}{ Challenged groups } \\
\hline & NC & OMAE & PC & $\mathrm{PC}+\mathrm{OMAE}$ \\
\hline \multicolumn{5}{|l|}{ Serum Chemistry } \\
\hline AST $(U / L)$ & $142.75 \pm 6.55^{a}$ & $145.25 \pm 2.06^{a}$ & $142.25 \pm 5.91^{\mathrm{a}}$ & $147.25 \pm 8.96^{a}$ \\
\hline ALT (U/L) & $1.75 \pm 0.50^{\mathrm{a}}$ & $1.75 \pm 0.50^{\mathrm{a}}$ & $1.50 \pm 0.58^{\mathrm{a}}$ & $1.75 \pm 0.50^{\mathrm{a}}$ \\
\hline GGT (U/L) & $11.75 \pm 0.96^{\mathrm{a}}$ & $12.00 \pm 0.82^{\mathrm{a}}$ & $11.50 \pm 0.58^{a}$ & $12.00 \pm 1.41^{\mathrm{a}}$ \\
\hline $\operatorname{ALP}(\mathrm{U} / \mathrm{L})$ & $12482 \pm 1839.18^{a b}$ & $12755 \pm 1506.30^{a}$ & $7590 \pm 1205.17^{c}$ & $9732 \pm 726.28^{b c}$ \\
\hline LDH (U/L) & $671.50 \pm 20.02^{\mathrm{a}}$ & $679.25 \pm 18.93^{\mathrm{a}}$ & $682.50 \pm 75.72^{\mathrm{a}}$ & $672.25 \pm 29.51^{\mathrm{a}}$ \\
\hline $\mathrm{TG}(\mathrm{mg} / \mathrm{dl})$ & $73.33 \pm 4.99^{a}$ & $65.10 \pm 7.59^{\mathrm{ab}}$ & $51.50 \pm 3.42^{\mathrm{b}}$ & $60.50 \pm 11.00^{\mathrm{ab}}$ \\
\hline $\mathrm{TC}(\mathrm{mg} / \mathrm{dl})$ & $120.25 \pm 5.50^{\mathrm{a}}$ & $118.75 \pm 4.11^{\mathrm{a}}$ & $82.68 \pm 4.50^{c}$ & $98.83 \pm 6.21^{\mathrm{b}}$ \\
\hline $\mathrm{HDL}(\mathrm{mg} / \mathrm{dl})$ & $98.83 \pm 7.36^{\mathrm{a}}$ & $97.58 \pm 4.80^{\mathrm{a}}$ & $60.58 \pm 3.46^{c}$ & $84.33 \pm 6.18^{b}$ \\
\hline LDL (mg/dl) & $6.50 \pm 2.38^{\mathrm{bc}}$ & $7.75 \pm 2.06^{\mathrm{abc}}$ & $11.18 \pm 1.73^{a}$ & $5.00 \pm 1.41^{c}$ \\
\hline Glu (mg/dl) & $223.00 \pm 5.89^{c}$ & $229.00 \pm 4.55^{b c}$ & $238.50 \pm 6.81^{a}$ & $229.75 \pm 5.44^{b c}$ \\
\hline $\mathrm{UA}(\mathrm{mg} / \mathrm{dl})$ & $5.50 \pm 0.37^{\mathrm{a}}$ & $5.30 \pm 0.67^{\mathrm{a}}$ & $5.33 \pm 0.50^{\mathrm{a}}$ & $5.43 \pm 1.46^{\mathrm{a}}$ \\
\hline $\mathrm{TP}(\mathrm{gm} / \mathrm{dl})$ & $2.65 \pm 0.12^{\mathrm{ab}}$ & $2.75 \pm 0.05^{\mathrm{a}}$ & $2.19 \pm 0.15^{c}$ & $2.76 \pm 0.04^{a}$ \\
\hline \multicolumn{5}{|l|}{ Protein fractions } \\
\hline Alb (gm/dl) & $0.89 \pm 0.04^{\mathrm{bc}}$ & $0.98 \pm 0.02^{\mathrm{a}}$ & $0.67 \pm 0.04^{d}$ & $0.95 \pm 0.02^{\mathrm{ab}}$ \\
\hline$\alpha 1-\mathrm{g}(\mathrm{gm} / \mathrm{dl})$ & $0.07 \pm 0.00^{\mathrm{b}}$ & $0.08 \pm 0.02^{b}$ & $0.12 \pm 0.01^{\mathrm{a}}$ & $0.09 \pm 0.02^{\mathrm{b}}$ \\
\hline$\alpha 2-\mathrm{g}(\mathrm{gm} / \mathrm{dl})$ & $0.70 \pm 0.03^{a}$ & $0.70 \pm 0.03^{\mathrm{a}}$ & $0.56 \pm 0.01^{b}$ & $0.67 \pm 0.01^{\mathrm{a}}$ \\
\hline$\beta-\mathrm{g}(\mathrm{gm} / \mathrm{dl})$ & $0.56 \pm 0.05^{\mathrm{ab}}$ & $0.61 \pm 0.06^{\mathrm{a}}$ & $0.47 \pm 0.02^{c}$ & $0.63 \pm 0.01^{\mathrm{a}}$ \\
\hline$\gamma-\mathrm{g}(\mathrm{gm} / \mathrm{dl})$ & $0.43 \pm 0.01^{b}$ & $0.39 \pm 0.05^{b}$ & $0.51 \pm 0.05^{a}$ & $0.42 \pm 0.00^{b}$ \\
\hline A/G ratios & $0.51 \pm 0.02^{\mathrm{a}}$ & $0.55 \pm 0.02^{\mathrm{a}}$ & $0.40 \pm 0.03^{b}$ & $0.53 \pm 0.02^{\mathrm{a}}$ \\
\hline \multicolumn{5}{|c|}{ Antioxidant markers } \\
\hline GSH & $73.10 \pm 3.34^{\mathrm{b}}$ & $79.90 \pm 2.10^{\mathrm{a}}$ & $62.03 \pm 3.12^{c}$ & $73.10 \pm 1.64^{b}$ \\
\hline SOD & $599.50 \pm 41.03^{\mathrm{ab}}$ & $613.75 \pm 50.25^{a}$ & $375.13 \pm 54.43^{d}$ & $485.00 \pm 21.92^{\circ}$ \\
\hline CAT & $3.89 \pm 0.27^{\mathrm{b}}$ & $4.60 \pm 0.43^{\mathrm{a}}$ & $2.66 \pm 0.58^{d}$ & $3.58 \pm 0.16^{b c}$ \\
\hline
\end{tabular}

Data of each group were expressed as means \pm SD. Mean values in the same row bearing different superscript letters were significantly differ at $(P$ $<0.05)$.

increases compared to PC group (Table 2; $P<0.05$ ). Moreover, the serum concentrations of triglycerides and $L D L$ in $P C+O M A E$ group were non-significantly different compared to NC group (Table 2; $P>0.05$ ). In addition, significant increases in glucose concentrations were observed in PC group compared to NC group (Table 2; $P<0.05$ ), but their concentrations in $\mathrm{PC}+\mathrm{OMAE}$ group showed non-significant differences when compared to NC group (Table 2; $P>0.05$ ). Finally, there weren't significant differences in uric acid concentrations between all groups (Table 2; $P>0.05$ ).

\section{Serum protein electrophoresis}

Firstly, total protein concentrations in serum samples of all groups were measured by colorimetric method. Then, serum proteins were separated using cellulose acetate electrophoresis and five fractions (albumin, $\alpha 1-, \alpha 2-, \beta$ - and $\gamma$-globulins) were recognized in all samples. Total protein concentrations as well as the absolute concentrations of albumin, $\alpha 2$-globulins and $\beta$-globulin were significantly reduced in $\mathrm{PC}$ group compared to NC group (Table 2; $P<0.05$ ). Also, significant increases in absolute concentrations of $\alpha 1$ - and $\gamma$-globulins were observed in serum samples of PC group compared to NC group (Table 2; $P<0.05$ ). Furthermore, the mean values of albumin/globulin $(A / G)$ ratios were significantly diminished in $\mathrm{PC}$ group compared to NC group (Table 2; $P<0.05$ ). On the other hand, $\mathrm{PC}+\mathrm{OMAE}$ group showed non-significant changes in the concentrations of total protein, albumin, $\alpha 1-, \alpha 2-, \beta$ - and $\gamma$ - globulins, as well as in mean values of $\mathrm{A} / \mathrm{G}$ ratios compared to NC group (Table 2; $P$ $>0.05$ ).

\section{Antioxidant markers}

Significant decreases in GSH and CAT levels were determined in PC group compared to NC group (Table 2; $P<0.05$ ). However, their concentrations in $P C+O M A E$ group showed non- significant differences compared to NC group (Table 2; $P>0.05)$. Furthermore, significant decreases in SOD levels were observed in $\mathrm{PC}$ group compared to NC group (Table 2; $P<0.05)$. However, $P C+O M A E$ group showed significant increases in SOD levels when compared to PC group (Table 2; $P<0.05)$.

\section{Cecal Oocysts count}

The cecal contents of control groups were normal and free of coccidian oocysts. On the other hand, the cecal contents of broiler chicken in PC group were mixed with blood and $E$. tenella oocysts were detected and markedly increased day after day, indicating that infection was successful. But, significant decrease in oocysts count were observed in cecal contents of broiler chicken in PC+OMAE group from the day $6^{\text {th }}$ to the day $9^{\text {th }}$, compared to PC group (Table 3; $P<0.05$ ).

\section{Histopathology}

Histopathological findings of the intestinal sections of control groups showed normal morphological appearances (Figure 1). However, the intestine of broiler chicken in challenged groups has shown inflammatory cells infiltrations confined to focal mucosal localization and sometimes increased severity first included the submucosa and eventually led to transmural infiltrates (Figure 2a, b, c and $d$ ), erosion of the covering epithelium of the mucosa (Figure $3 a, b, c$ and d) extended to ulceration of the mucosa (Figure $4 a, b)$, destructive changes and necrosis in the crypt epithelium, villous atrophy and adhesion, and minimal to marked parasitic loads with different stages of the parasites at the covering and cryptic epithelium (Figure 5a, b, c and d). $P C$ group showed sever pathological changes (score 5), but $\mathrm{PC}+\mathrm{OMAE}$ group showed reduced histopathological changes of (score 3). 
Table 3. Effect of OMAE on cecal oocysts count of broiler chicken challenged with sporulated oocysts of $E$. tenella

\begin{tabular}{|c|c|c|c|c|}
\hline \multirow{2}{*}{ Days p.i. (Cecal oocystcount) } & \multicolumn{2}{|c|}{ Control groups } & \multicolumn{2}{|c|}{ Challenged groups } \\
\hline & NC & OMAE & PC & $\mathrm{PC}+\mathrm{OMAE}$ \\
\hline 0 day & - & - & - & - \\
\hline $6^{\text {Th }}\left(\times 10^{6} / \mathrm{gm}\right)$ & - & - & $0.5938 \pm 269.12^{\mathrm{a}}$ & $0.0399 \pm 107.02^{b}$ \\
\hline $7^{\text {th }}\left(\times 10^{6} / g m\right)$ & - & - & $2.0855 \pm 1408.86^{a}$ & $1.3293 \pm 866.50^{b}$ \\
\hline $8^{\text {Th }}\left(\times 10^{6} / \mathrm{gm}\right)$ & - & - & $4.5760 \pm 3942.22^{\mathrm{a}}$ & $1.5392 \pm 1708.19^{b}$ \\
\hline $9^{\text {Th }}\left(\times 10^{6} / \mathrm{gm}\right)$ & - & - & $5.1150 \pm 1887.68^{a}$ & $1.7545 \pm 1179.31^{b}$ \\
\hline
\end{tabular}

Data of each group were expressed as means \pm SD. Mean values in the same row bearing different superscript letters were significantly differ at $(P$ $<0.05)$.

Table 4. Scoring scheme for cecal and colonic inflammation in broiler chicken challenged with sporulated oocysts of E. tenella

\begin{tabular}{|c|c|c|c|c|c|}
\hline \multicolumn{2}{|c|}{ Inflammatory cell infiltrate } & \multicolumn{2}{|c|}{ Intestinal architecture } & \multirow[t]{2}{*}{ Parasitic load } & \multirow[t]{2}{*}{ Score } \\
\hline Severity & Extent & Epithelial change & Mucosal architecture & & \\
\hline Minimal & Mucosa & Intact epithelium & & Minimal & 1 \\
\hline Mild & $\begin{array}{l}\text { Mucosa, sometimes } \\
\text { extending into submucosa }\end{array}$ & Focal Erosions & & Mild & 2 \\
\hline Moderate & Mucosa and submucosa & Erosions & Focal ulcerations & Moderate & 3 \\
\hline Marked & Mucosa and submucosa & & Focal ulcerations & Marked & 4 \\
\hline Marked & $\begin{array}{c}\text { Mucosa, submucosa and } \\
\text { transmural }\end{array}$ & & Extended ulcerations & Marked & 5 \\
\hline
\end{tabular}

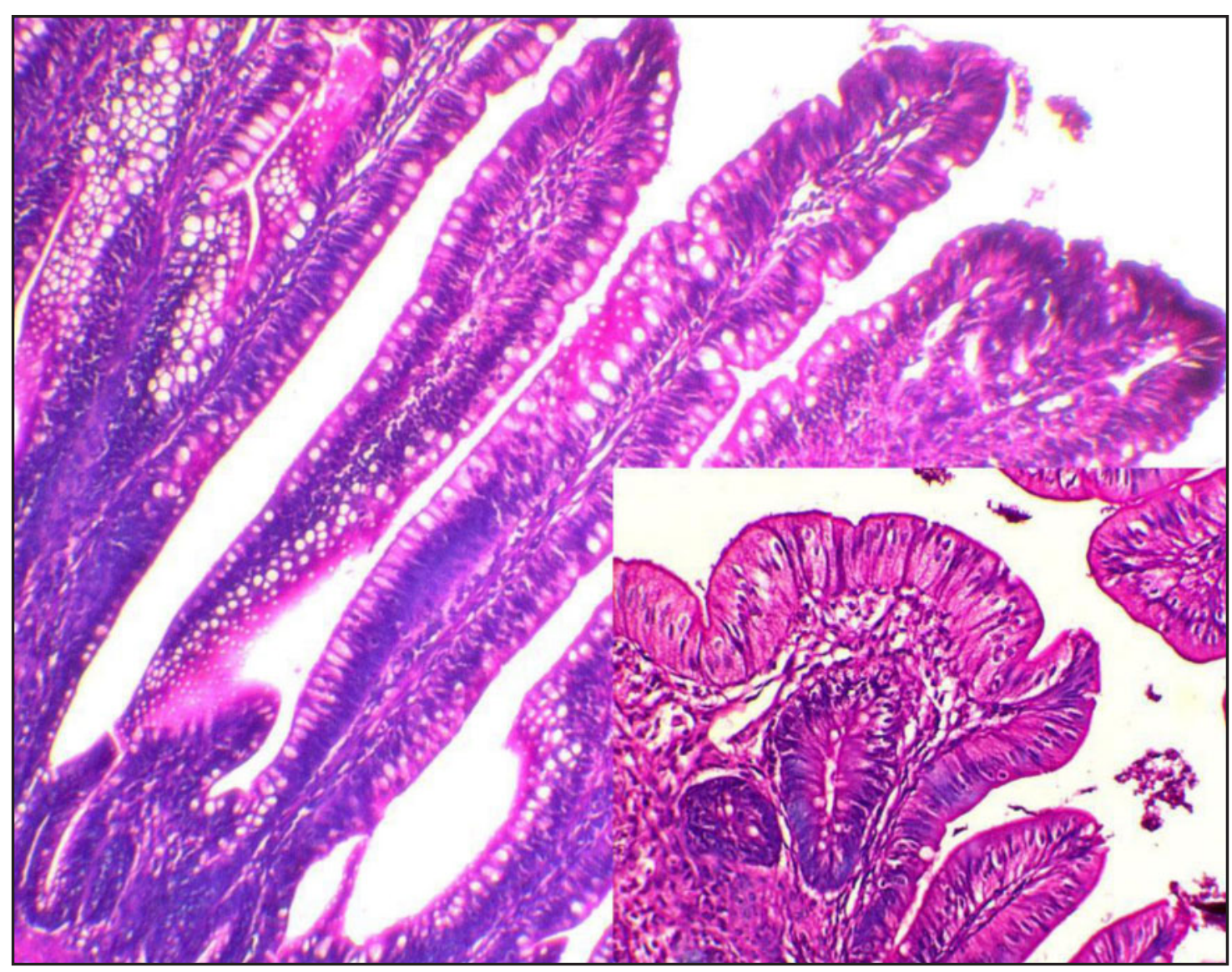

Figure 1. Intestine showing normal morphological appearance. ( $H$ and $E, \times 100,200)$. 


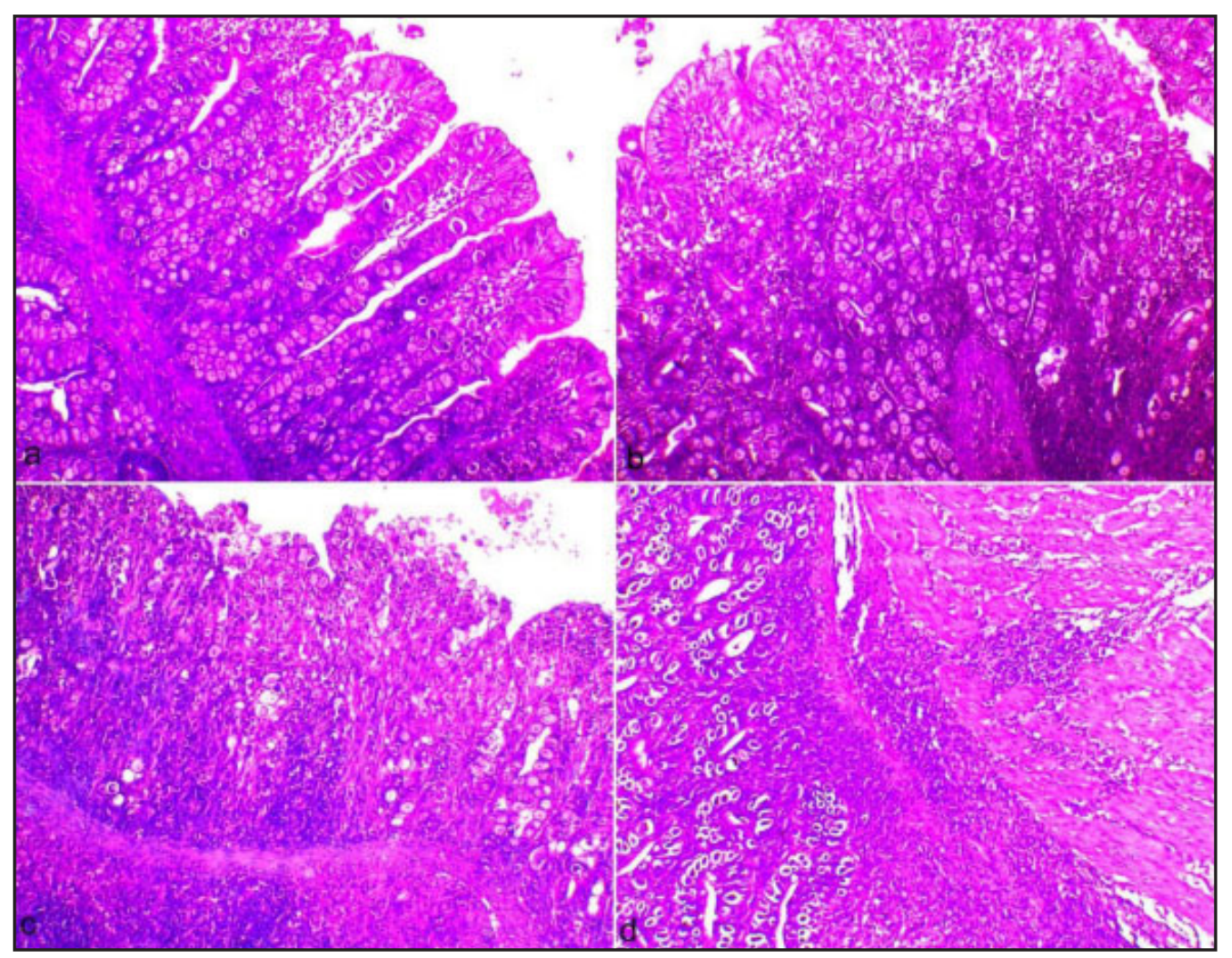

Figure 2. a) Intestine showing minimal mucosal inflammatory cell infiltrates with intact epithelium. b) Intestine showing mucosal and submucosal inflammatory cell infiltrates with intact epithelium. c) Intestine showing mucosal and submucosal inflammatory cell infiltrates with degenerated epithelium. d) Intestine showing transmural infiltrates (arrow) ( $\mathrm{H}$ and $\mathrm{E}, \times 100$ ).

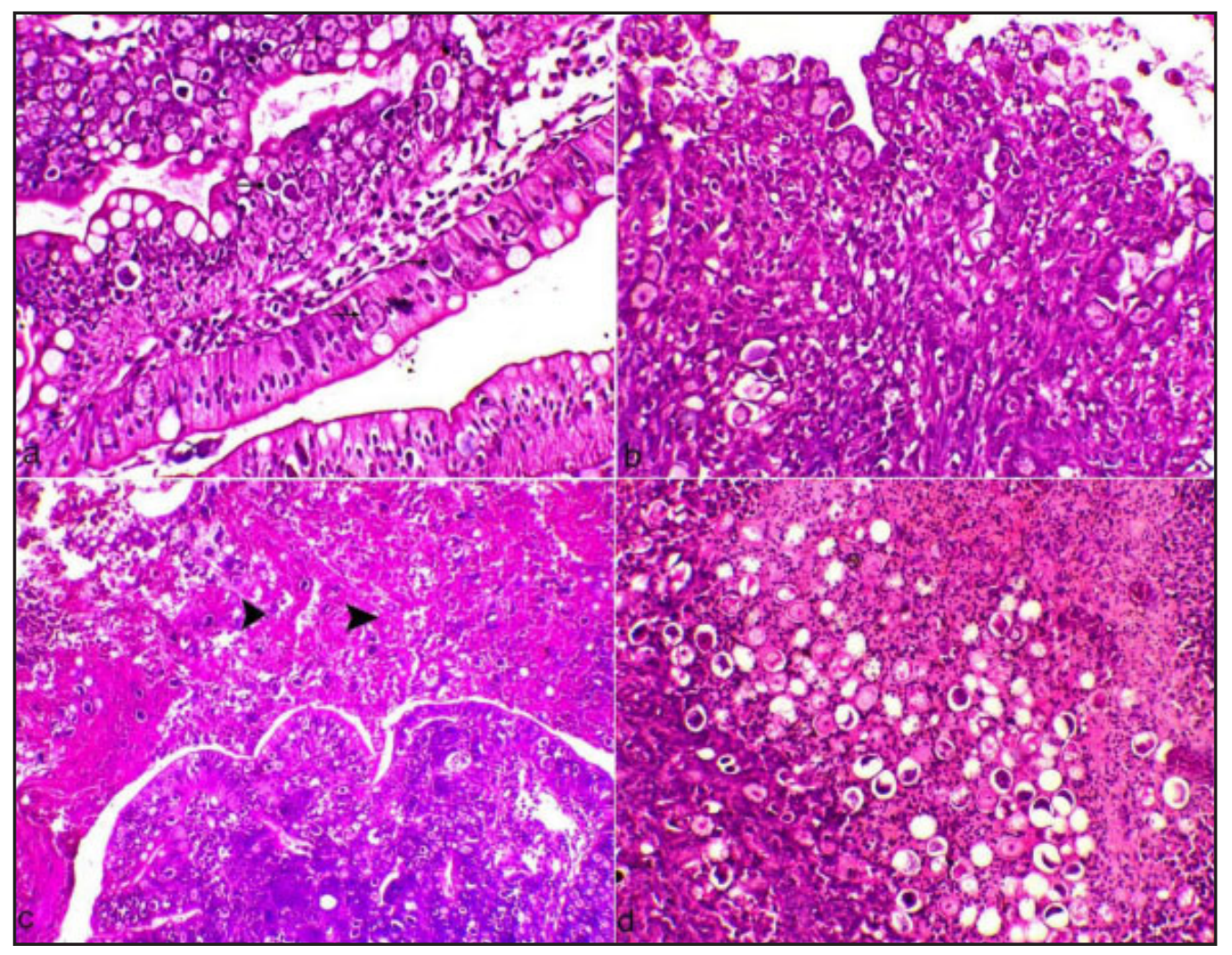

Figure 3. a) Intestine showing intact epithelium with parasitic oocytes (arrows). b) Intestine showing degeneration of the covering epithelium. c) Intestine showing degenerated covering epithelium and sloughing of the epithelium into the intestinal lumen (head arrows) together with parasitic oocytes. d) Intestinal lumen showing hemorrhage, parasitic oocytes and sloughing of the epithelium ( $H$ and $E, \times 100,200)$. 


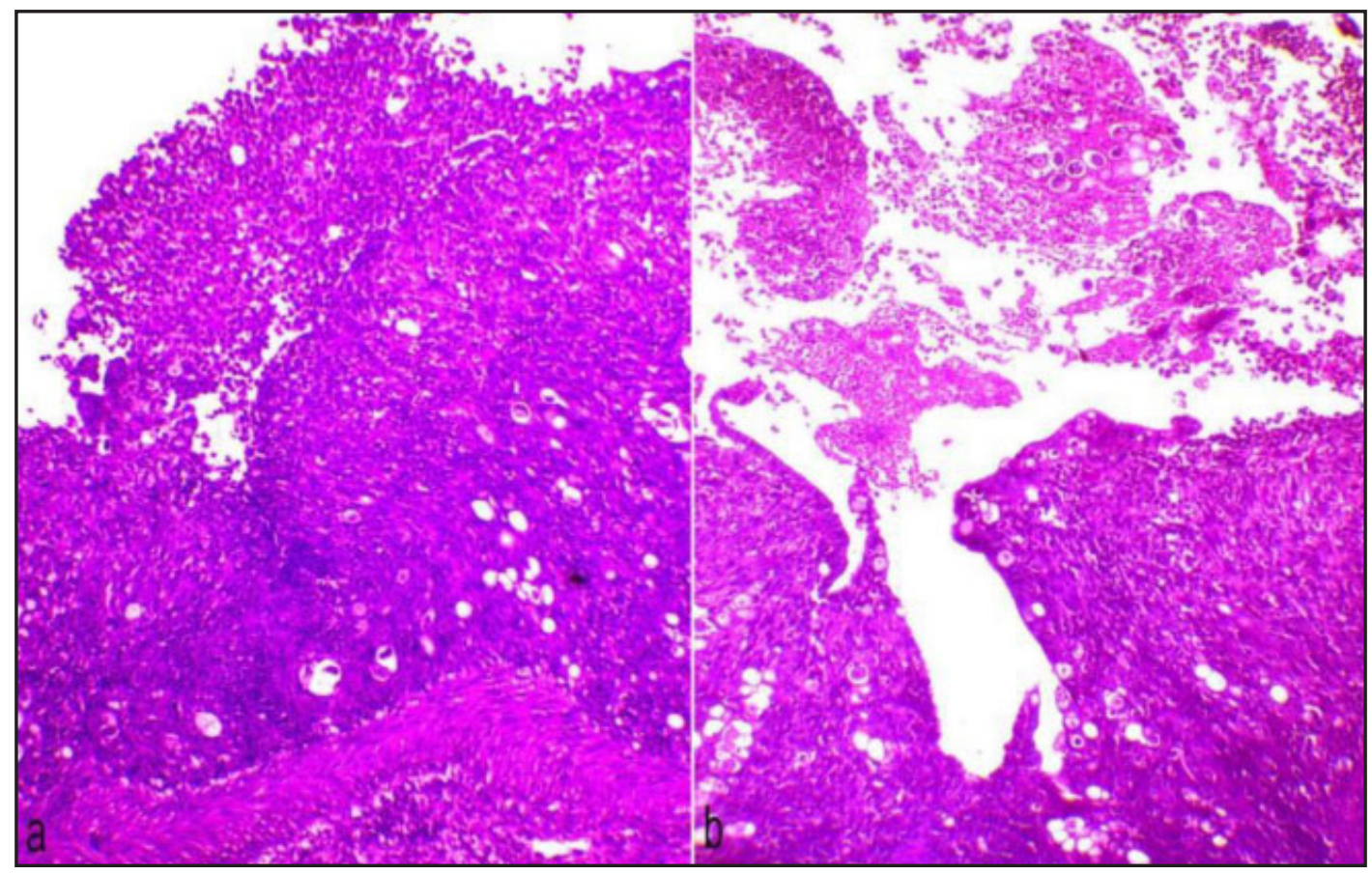

Figure 4. $\mathbf{a}$ and $\mathbf{b}$. Intestine showing ulceration of the mucosa, marked inflammatory cells infiltrations and sloughing the covering epithelium into the lumen of the intestine. ( $H$ and $E, \times 100)$.

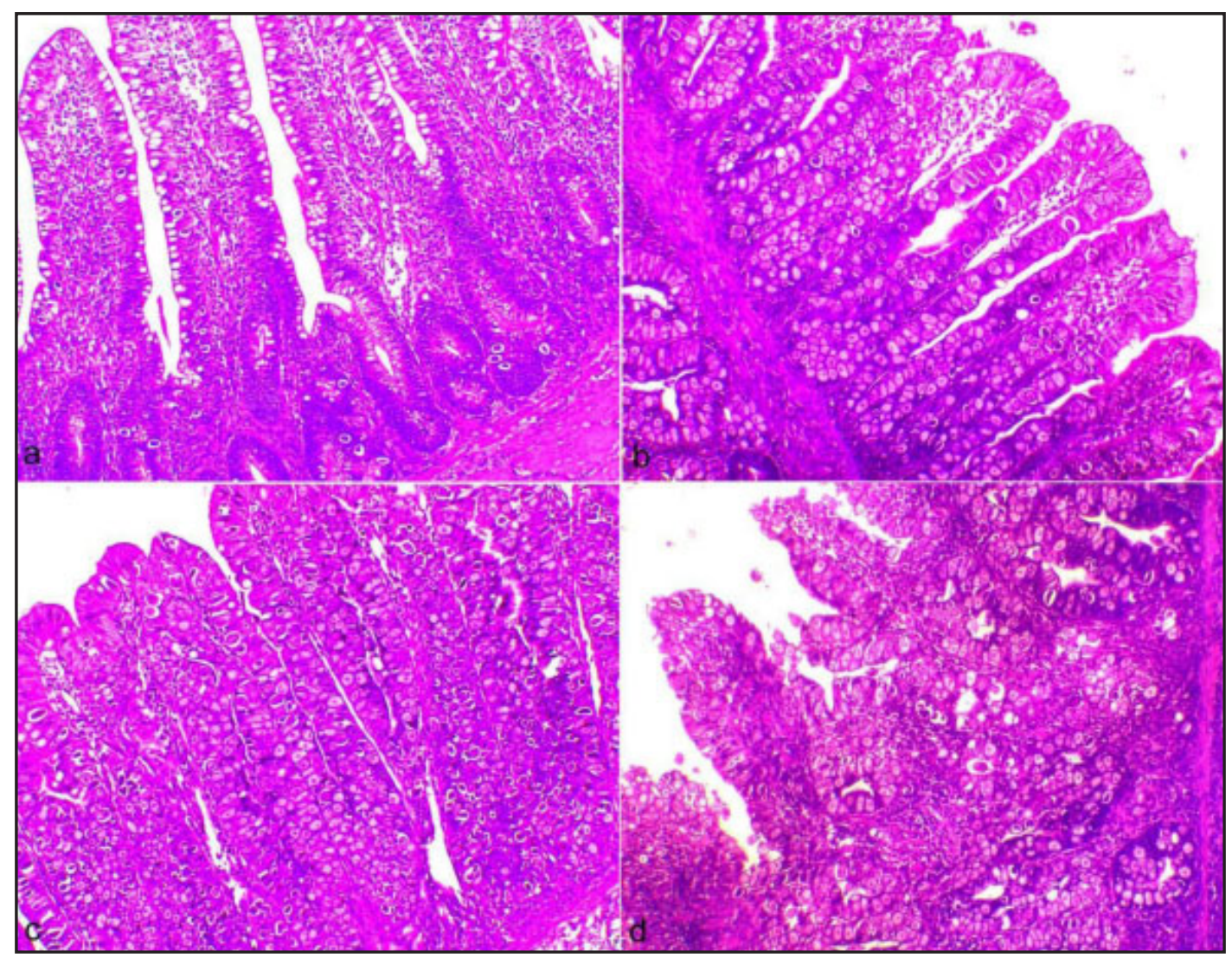

Figure 5. a) Intestine showing minimal parasitic loads. b) Intestine showing moderate parasitic loads. c) Intestine showing marked parasitic loads. d) Intestine showing marked parasitic loads at the covering and cryptic epithelium ( $H$ and $E, \times 100)$. 


\section{DISCUSSION}

Coccidiosis, an enteric protozoal disease caused by several Eimeria species, remains one of the greatest burdens on the economics of production of poultry and poultry derived products (Blake \& Tomley, 2014). E. tenella has been recognized as the most pathogenic species due to its hemorrhagic pathologies and high mortality rate following infection (Matsubayashi et al., 2019). Currently, control measures of coccidiosis mainly include chemotherapy, vaccines, and herbal products administered prophylactically. However, it becomes a challenge for poultry producers to keep profits facing the development of drug and chemical resistance and increased medication costs (Tellez et al., 2014). Consequently, the purpose of present study was to assess the potential anticoccidial effect of OMAE, as an oral liquid preparation, in E. tenella-infected chicken.

The current study demonstrated significant decreases in the mean values of erythrocyte counts, Hb levels, and PCV in broiler chicks challenged with sporulated oocysts of $E$. tenella on day $6^{\text {th }}$ p.i. Early, it have been reported that the erythrocyte count and hematocrit value of birds infected with cecal coccidiosis were shown to decrease $50 \%$ on the $5^{\text {th }}$ and $6^{\text {th }}$ days p.i. (Natt $\&$ Herrick, 1955). Also, recent study reported by Dar et al. (2014) showed a significant reduction in erythrocyte count, $\mathrm{PCV}$, and $\mathrm{Hb}$ values in $E$. tenella infected broilers. The reduction in $\mathrm{Hb}$ and total erythrocytes count may be attributed to cecal hemorrhages. This hemorrhage may be due to mechanical disruption of mucosal capillaries by pressure resulting from the expansion of cecal epithelial cells in which the schizogony has been occurred (Natt \& Herrick, 1955). Also, significant leukocytosis, heterophilia, and momocytosis and non-significant lymphocytopenia were observed in chicken infected with sporulated oocysts of $E$. tenella. Before, it has been reported that $E$. tenella infection causes marked leukocytosis, lymphopenia, and heterophilia (Natt, 1959). Also, Dar et al. (2014) reported a marked increase in total leukocyte count in broiler chicken infected with $E$. tenella. Higher total leukocyte count may be attributed to heterophilia in response to tissue damage caused by $E$. tenella infection. Heterophils contain a diversity of granules that subscribe to the first line host defense against bacteria, fungi, protozoa and some viruses (Wakenell, 2010). In pet birds, acute or chronic inflammatory disease is the predominant cause of monocytosis or heterophilia as they are essential hematopoietic cells that play critical roles in defense and in maintaining homeostasis (Irizaary-Rovira, 2004).

Regarding biochemical serum analysis, significant decreases in ALP activities were observed in chicken infected with E. tenella. Earlier, Kogut and Powell (1993) had reported that serum ALP activity was inversely proportional to both oocyst dose and gross intestinal lesion score in certain coccidial infections. Metabolic changes and bone marrow damages with severe growth depression associated with $E$. tenella infection in broiler chicken may result in significant decrease of ALP (Patra et al., 2010). Also, in present study, significant lower concentrations of serum total protein were observed in infected chicken. The reduction in total plasma protein in broiler chicken infected with $E$. tenella may be attributable to reduced feed intake, hemorrhagic enteritis that leads to reduced absorption of amino acids and development of inflammatory exudates rich in blood proteins, stress that leads to cortisol secretion and catabolism of protein, and rapid movement of interstitial fluid without protein into the plasma compartment (Mondal et al., 2011). Moreover, serum triglycerides, cholesterol and HDL concentrations were significantly decreases in broiler chicken infected with E. tenella. The total plasma carotenoids and lipids were significantly depressed by E. tenella infected chicken (Conway et al., 1993). Declined triglyceride level in the coccidia affected birds may be attributed to anorexia, high glucagon level that inhibit fatty acid synthesis, and disturbance in vitamin B synthesis that hinder lipogenesis from carbohydrate (Allen \& Mc Murtry, 1984; Mondal et al., 2011). Additionally, the present study revealed a significant higher levels in glucose levels in E. tenella infected chicken. Detected hyperglycemia may be attributed to stress or low feed intake during acute infective stage which induce the release of adrenal cortisones/corticosteroids increasing glycogenolysis process (Patra et al., 2010).

Electrophoretic protein fractions in E. tenella infected birds showed significant changes in their concentrations. While the albumin, $\alpha 2$ - and $\beta$-globulins, and $A / G$ ratios were lower, the higher concentrations were observed for $\alpha 1-$ and $\gamma$-globulins. These results are partially in agreement with Ruff and Augustine (1982) who had reported a significant decrease in albumin and increase in the alpha 1 , beta, and gamma 1 globulins increased in E. tenella-infected chicken. The decrease of albumin may be attributed to malnourishment, gastrointestinal diseases, intestinal parasitism, increased catabolism, and hepatic and renal diseases. In addition, albumin concentration falls gradually during infectious and inflammatory disease (Eckersall, 1997). Furthermore, electrophoretic patterns in acute inflammation, typically demonstrate increased concentration of alpha and/or beta globulins; however, gamma globulin (immunoglobulins) increases may also be observed (Campbell, 2012). Furthermore, in acute inflammatory conditions, the A/G ratios automatically decrease due to a decrease of albumin and an increase of globulin fractions. Supplementation of OMAE could improve almost changes occurred in hematology and biochemistry parameters compared to infected and noninfected birds. Such extract might inhibited or postponed the initiation of oxidative cellular damage associated with Eimeria infection in broilers chicken because of their antioxidant and free radical scavenging activities.

Furthermore, our data indicated that chicken challenged with $E$. tenella showed significant lower levels of cecal antioxidant markers including GSH, SOD, and CAT. Instead, supplementation of OMAE in E. tenella infected chicken could restore the normal balance of cecal antioxidant markers suggesting the powerful in vivo antioxidant enhancing capacity of such extract. Several reports stated that broiler chicken infected with Eimeria reveal increased free radicals formation, alterations in antioxidant enzyme activities, and reduced concentrations of non-enzymatic antioxidants (Allen, 1997; Georgieva et al., 2006; Khatlab et al., 2019).

Parasitological analysis showed that cecal oocysts count of $E$. tenella-infected chicken was high on the day $6^{\text {th }}$ p.i. and markedly increase day after day till the day $9^{\text {th }}$, indicating that challenge was successful. The incubation periods generally range from 4 to 5 days following oral infection and maximum oocyst output ranges from 6 to 9 days p.i. (Tewari \& Maharana, 2011). In our experiment, supplementation of OMAE decreased the oocysts count from the day $6^{\text {th }}$ to the day $9^{\text {th }}$ p.i. when compared to E. tenella group, suggesting a potential anticoccidial activity of OMAE. Kozlowska et al. (2010) have documented that volatile oil and different extracts of the OM leaves have shown in vitro anti-protozoal effect against single protozoan species Pentatrichomonas hominis. 
Finally, histopathological examination revealed that $E$. tenella infection was accompanied by marked cecal lesion (score 5). Many cell types within the mucosa of the gastrointestinal (GI) tract produce free radicals as consequences of normal cellular metabolism. However, uncontrolled production of reactive oxygen species lead to cellular proteins damage and disruption of $\mathrm{Gl}$ tract barrier to increase gut permeability which contributes to inflammation. Furthermore, excess reactive oxygen species stimulate polymorphonuclear leukocytes, in that way causing further damage to the tissue (Bhattacharyya, 2014). Lymphokines elaborated by lymphocytes infiltrating the lamina propria of the ceca during $E$. tenella infection stimulate NO production in vascular endothelium which lead to vasodilation of cecal blood vessels and enhance hemorrhage (Allen, 1997). Also, unbalanced oxidant/antioxidant status of chicken infected with $E$. tenella is important in the development of disease (Georgieva et al., 2006). Moreover, it was stated that coccidiosis is associated with increased generation of reactive oxygen species due to activities of the parasite as well as cellular response of the host which reduce the antioxidant enzymes and GSH levels of cells in intestinal linings (Gotep et al., 2016). Antioxidants can relieve the damage to the intestinal tissue throughout parasite invasion by decreasing the cytotoxic effects caused by the reactive oxygen species (Idris et al., 2017). Our data showed that supplementation of OMAE could reduce the cecal lesion score to grade 3 suggesting that multiplication of $E$. tenella is inhibited or delayed by their antioxidant components.

\section{CONCLUSION}

Collectively, restored oxidant-antioxidant balance along with reduced cecal lesion and oocysts count and subsequently improved changes in hemato-biochemical parameters revealed for the first time that OMAE can be used as an alternative remedy for alleviating coccidiosis and reducing its severity in broiler chicken.

\section{Conflict of interest statement}

The authors report no conflicts of interest associated with this manuscript.

\section{REFERENCES}

Al-Harbi, N. (2011). Effect of marjoram extract treatment on the cytological and biochemical changes induced by cyclophosphamide in mice. Journal of Medicinal Plant Research 5: 5479-5485. https://doi.org/10.5897/JMPR. 9000483

Allen, P.C. \& McMurtry, J.P. (1984). Changes in pancreatic hormones associated with coccidiosis. Poultry Science 63: 1129-1135. https://doi.org/10.3382/ps.0631129

Allen, P.C. (1997). Nitric oxide production during Eimeria tenella infections in chickens. Poultry Science 76: 810-813. https://doi.org/10.1093/ps/76.6.810

Bancroft, J.D. \& Gamble, M. (2007). Theory and Practice of Histological Techniques. 5th ed. Edinburgh: Churchill Livingstone Pub.

Barbour, E.K., Ayyash, D.B., Iyer, A., Harakeh, S. \& Kumosani, T. (2015). A Review of Approaches Targeting the Replacement of Coccidiostat Application in Poultry Production. Brazilian Journal of Poultry Science 17: 405-418. https://doi.org/10.1590/ 1516-635x1704405-418

Beutler, E., Duron, O. \& Kelly, B.M. (1963). Improved method for the determination of blood glutathione. Journal of Laboratory and Clinical Medicine 61: 882-888.
Bhattacharyya, A., Chattopadhyay, R., Mitra, S. \& Crowe, S.E. (2014). Oxidative stress: an essential factor in the pathogenesis of gastrointestinal mucosal diseases. Physiological reviews 94: 329-354. https://doi.org/10.1152/ physrev.00040.2012

Bina, F. \& Rahimi, R. (2017). Sweet Marjoram: A Review of Ethnopharmacology, Phytochemistry, and Biological Activities. Evidence-Based Complementary and Alternative Medicine 22: 175-185. https://doi.org/10.1177/2156587 216650793

Blake, D.P., Knox, J., Dehaeck, B., Huntington, B., Rathinam, T., Ravipati, V., Ayoade, S., Gilbert, W., Adebambo, A., Jatau, I., Raman, M., Parker, D., Rushton, J. \& Tomley, F. (2020). Re-calculating the cost of coccidiosis in chickens. Veterinary Research 51: 1-14. https://doi.org/10.1186/s13567-02000837-2

Blake, D.P. \& Tomley, F.M. (2014). Securing poultry production from the ever-present Eimeria challenge. Trends in Parasitology 30: 12-19. https://doi.org/10.1016/j.pt.2013. 10.003

Campbell, T.W. (2012). Clinical Chemistry of Birds. In: Thrall, M.A., Weiser, G., Allison, R.W. \& Campbell, T.W., (editors): Veterinary Hematology and Clinical Chemistry. 2nd ed. Ames, IA, USA: Wiley-Blackwell; pp. 582-598.

Chen, H.L., Zhao, X.Y., Zhao, G.X., Huang, H.B., Li, H.R., Shi, C.W., Yang, W.T., Wang, J.Z., Ye, L.P., Zhao, Q., Wang, C.F. \& Yang, G. (2020). Dissection of the cecal microbial community in chickens after Eimeria tenella infection. Parasites \& Vectors. 13: 56. https://doi.org/10.1186/s13071-020-3897-6

Chishti, S., Kaloo, Z.A. \& Sultan, P. (2013). Medical importance of genus Origanum: A review. Journal of Pharmacognosy and Phytotherapy 5: 170-177. https://doi.org/10.5897/ JPP2013.0285

Coles, E.H. (1986). Veterinary Clinical Pathology. 4th ed., Philadelphia, USA: Saunders.

Coles, G.C., Bauer, C., Borgsteede, F.H.M., Geerts, S., Klei, T.R., Taylor, M.A. \& Waller, P.J. (1992). World Association for the Advancement of Veterinary Parasitology (W.A.A.V.P.) methods for the detection of anthelmintic resistance in nematodes of veterinary importance. Veterinary Parasitology 44: 35-44. https://doi.org/10.1016/0304-4017(92) 90141-U

Conway, D.P., Sasai, K., Gaafar, S.M. \& Smothers, C.D. (1993). Effects of different levels of oocyst inocula of Eimeria acervulina, E. tenella, and E. maxima on plasma constituents, packed cell volume, lesion scores, and performance in chickens. Avian Diseases 37: 118-123.

Dalloul, R.A. \& Lillehoj, H.S. (2006). Poultry coccidiosis: recent advancements in control measures and vaccine development. Expert Review of Vaccines 5: 143-163. https:// doi.org/10.1586/14760584.5.1.143

Dar, A., Verma, P., Ashfaque, M., Ahmad, A. \& Mir, I.A. (2014). Effect of Garlic Extract on Haematobiochemical Changes in Eimeria tenella Infected Broiler Chicken. National Academy Science Letters 37: 311-316. https://doi.org/10.1007/ s40009-014-0237-4

Deuschle, R., Deuschle, V., Bonfanti-Azzolin, G., Oliveira, J., Sostisso, Q., Goulart, J., Mayer, M., Horn, R. \& Golle, D. (2018). Phytochemical Screening and Antioxidant Activity of Origanum majorana Against Oxidative Stress Biomarkers. Journal of Agricultural Science 10: 395. https://doi. org/10.5539/jas.v10n12p395

Duletic, S., Alimpić Aradski, A., Kolarevic, S., Vuković-Gacić, B., Oaldje, M., Zivković, J., Šavikin, K. \& Marin, P. (2018). Antineurodegenerative, antioxidant and antibacterial activities and phenolic components of Origanum majorana 
L. (Lamiaceae) extracts. Journal of Applied Botany and Food Quality 91. https://doi.org/10.5073/JABFQ.2018.091.018

Eckersall, D. (1997). Proteins, Proteomics, and the Dysproteinemias. In: Kaneko JJ, Harvey JW, Bruss ML, (editors). Clinical Biochemistry of Domestic Animals. 6th ed. San Diego, USA: Academic Press Inc., pp. 116-155.

Erben, U., Loddenkemper, C., Doerfel, K., Spieckermann, S., Haller, D., Heimesaat, M.M., Zeitz, M., Siegmund, B. \& Kühl, A.A. (2014). A guide to histomorphological evaluation of intestinal inflammation in mouse models. International Journal of Clinical and Experimental Pathology 7: 4557-4576.

Georgieva, N.V., Koinarski, V. \& Gadjeva, V. (2006). Antioxidant status during the course of Eimeria tenella infection in broiler chickens. Veterinary Journal 172: 488-492. https:// doi.org/10.1016/j.tvjl.2005.07.016

Gotep, J.G., Tanko, J.T., Forcados, G.E., Muraina, I.A., Ozele, N., Dogonyaro, B.B., Oladipo, O.O., Makoshi, M.S., Akanbi, O., Kinjir, H., Samuel, A.L., Onyiche, T.E., Ochigbo, G.O., Aladelokun, O.B., Ozoani, H.A., Viyoff, V.Z., Dapuliga, C.C., Atiku, A.A., Okewole, P.A., Shamaki, D., Ahmed, M.S. \& Nduaka, C.I. (2016). Therapeutic and Safety Evaluation of Combined Aqueous Extracts of Azadirachta indica and Khaya senegalensis in Chickens Experimentally Infected with Eimeria Oocysts. Journal of Parasitology Research 2016: 4692424. https://doi.org/10.1155/2016/4692424

Greer, J.M., Arber, D.A., Glader, B., List, A.F., Means, Jr. R.T., Rodgers, G.M., Appelbaum, F.R., Dispenzieri, A. \& Fehniger, T.A. (2014). Wintrobe's Clinical Hematology. 13th ed. Philadelphia, USA: Wolters Kluwer Lippincott Williams \& Wilkins Health.

Idris, M., Abbas, R., Masood, S., Rehman, T., Farooq, U., Babar, W., Hussain, R., Raza, A. \& Riaz, U. (2017). The potential of antioxidant rich essential oils against avian coccidiosis. World's Poultry Science Journal 73: 89-104. https://doi.org/ $10.1017 /$ S0043933916000787

Irizaary-Rovira, A.R. (2004). Avian and reptilian clinical pathology (Avian hematology \& biochemical analysis), Section XI, In Cowell RL (editor). Veterinary Clinical Pathology Secrets. St. Louis, MO, USA: Elsevier Inc., pp. 282-313.

Jordan, A., Caldwell, D.J., Klein, J., Coppedge, J., Pohl, S., FitzCoy, S. \& Lee, J.T. (2011). Eimeria tenella oocyst shedding and output in cecal or fecal contents following experimental challenge in broilers. Poultry Science 90: 990-995. https://doi.org/10.3382/ps.2010-01228

Joyner, L.P. \& Long, P.L. (1974). The specific characters of the Eimeria, with special reference to the coccidia of the fowl. Avian Pathology 3: 145-157. https://doi.org/10.1080/ 03079457409353827

Kadykalo, S., Roberts, T., Thompson, M., Wilson, J., Lang, M. \& Espeisse, O. (2018). The value of anticoccidials for sustainable global poultry production. International Journal of Antimicrobial Agents 51: 304-310. https://doi.org/10.1016/ j.ijantimicag.2017.09.004

Khatlab, A.S., Del Vesco, A.P., de Oliveira Neto, A.R., Fernandes, R.P.M. \& Gasparino, E. (2019). Dietary supplementation with free methionine or methionine dipeptide mitigates intestinal oxidative stress induced by Eimeria spp. challenge in broiler chickens. Journal of Animal Science and Biotechnology 10: 58. https://doi.org/10.1186/s40104-0190353-6

Kogut, M.H. \& Powell, K.C. (1993). Preliminary findings of alterations in serum alkaline phosphatase activity in chickens during coccidial infections. Journal of Comparative Pathology 108: 113-119. https://doi.org/10.1016/S00219975(08)80215-0
Kozłowska, M., Laudy, A., Starościak, B.J., Napiorkowski, A., Chomicz, L. \& Kazimierczuk, Z. (2010). Antimicrobial and antiprotozoal effect of sweet marjoram (Origanum majorana L.). Acta Scientiarum Polonorum, Hortorum Cultus 9: 133-141.

Kumar, B., Kumar, R., Tamizhmani, T., Rahiman, F. \& Mohamed, K. (2011). Majorana hortensis (M.): A review update. PHARMA SCIENCE MONITOR. 2011.

Macdonald, S.E., van Diemen, P.M., Martineau, H., Stevens, M.P., Tomley, F.M., Stabler, R.A. \& Blakea, D.P. (2019). Impact of Eimeria tenella coinfection on Campylobacter jejuni colonization of the chicken. Infection and Immunity 87: e00772-18. https://doi.org/10.1128/IAI.00772-18

Matsubayashi, M., Inaoka, D.K., Komatsuya, K., Hatta, T., Kawahara, F., Sakamoto, K., Hikosaka, K., Yamagishi, J., Sasai, K., Shiba, T., Harada, S., Tsuji, N. \& Kita, K. (2019). Novel characteristics of mitochondrial electron transport chain from Eimeria tenella. Genes 10: 29. https://doi.org/ 10.3390/genes 10010029

Mondal, D., Chattopadhyay, S., Batabyal, S., Bera, A. \& Bhattacharya, D. (2011). Plasma biochemical indices at various stages of infection with a field isolate of Eimeria tenella in broiler chicken. Veterinary World 4: 404. https:// doi.org/ 10.5455/vetworld.2011.404-409

Natt, M.P. \& Herrick, C.A. (1952). A new blood diluent for counting the erythrocytes and leucocytes of the chicken. Poultry Science 31: 735-738. https://doi.org/10.3382/ ps.0310735

Natt, M.P. \& Herrick, C.A. (1955). The effect of cecal coccidiosis on the blood cells of the domestic fowl: 1 . A Comparison of the Changes in the Erythrocyte Count Resulting from Hemorrhage in Infected and Mechanically Bled Birds. The use of the Hematocrit Value as an Index of the Severity of the Hemorrhage Resulting from the Infection. Poultry Science 34: 1100-1106. https://doi.org/10.3382/ps.0341100

Natt, M.P. (1959). The effect of cecal coccidiosis on the blood cells of the domestic fowl. 3. The changes in the leukocyte picture during the course of the infection. Experimental Parasitology 8: 182-187. https://doi.org/10.1016/00144894(59)90017-7

Paoletti, F. \& Mocali, A. (1990). Determination of superoxide dismutase activity by purely chemical system based on $\mathrm{NAD}(\mathrm{P}) \mathrm{H}$ oxidation. Methods in Enzymology 186: 209-220. https://doi.org/10.1016/0076-6879(90)86110-h

Patra, G., Ali, M., Chanu, K.H., Lalsiamthara, J., Joy, L.K., Prava, M., Ravindran, R., Das, G. \& Devi, L. (2010). PCR Based Diagnosis of Eimeria tenella Infection in Broiler Chicken. International Journal of Poultry Science 9. https://doi.org/ 10.3923/ijps.2010.813.818

Peek, H.W. \& Landman, W.J. (2011). Coccidiosis in poultry: anticoccidial products, vaccines and other prevention strategies. The Veterinary Quarterly 31: 143-161. https:// doi.org/10.1080/01652176.2011.605247

Prerna, P. \& Vasudeva, N. (2015). Origanum majorana L. - Phytopharmacological review. Indian Journal of Natural Products and Resources 6: 261-267.

Quiroz-Castañeda, R.E. \& Dantán-González, E. (2015). Control of avian coccidiosis: future and present natural alternatives. BioMed Research International 430610. https:// doi.org/10.1155/2015/430610

Ramadan, G., El-Beih, N.M., Arafa, N.M. \& Zahra, M.M. (2013). Preventive effects of Egyptian sweet marjoram (Origanum majorana L.) leaves on haematological changes and cardiotoxicity in isoproterenol-treated albino rats. Cardiovascular Toxicology 13: 100-109. https://doi.org/10.1007/ s12012-012-9189-4 
Ritzi, M.M., Abdelrahman, W., Mohnl, M. \& Dalloul, R.A. (2014). Effects of probiotics and application methods on performance and response of broiler chickens to an Eimeria challenge. Poultry Science 93: 2772-2778. https:// doi.org/10.3382/ps.2014-04207

Ruff, M.D. \& Augustine, P.C. (1982). Effects of coccidiosis on the electrophoretic pattern of serum proteins in chickens. Journal of Parasitology 68: 107-111.

Sinha, A.K. (1972). Colorimetric assay of catalase. Analytical Biochemistry 47: 389-394. https://doi.org/10.1016/00032697(72)90132-7

Tellez, G., Shivaramaiah, S., Barta, J., Hernandez-Velasco, X. \& Hargis, B. (2014). Coccidiosis: recent advancements in the immunobiology of Eimeria species, preventive measures, and the importance of vaccination as a control tool against these Apicomplexan parasites. Veterinary Medicine: Research and Reports 23. https://doi.org/10.2147/ VMRR.S57839

Tewari, A.K. \& Maharana, B.R. (2011). Control of poultry coccidiosis: changing trends. Journal of Parasitic Diseases 35: 10-17. https://doi.org/10.1007/s12639-011-0034-7

Triantaphyllou, K., Blekas, G. \& Boskou, D. (2001). Antioxidative properties of water extracts obtained from herbs of the species Lamiaceae. International Journal of Food Sciences and Nutrition 52: 313-317. https://doi.org/10.1080/ 09637480120057512

Vagi, E., Rapavi, E., Hadolin, M., Vasarhelyine Peredi, K., Balazs, A., Blázovics, A. \& Simándi, B. (2005). Phenolic and triterpenoid antioxidants from Origanum majorana L. herb and extracts obtained with different solvents. Journal of Agricultural and Food Chemistry 53: 17-21. https://doi.org/ $10.1021 /$ jf048777p

Wakenell, P.S. (2010). Hematology of chickens and turkeys. In: Weiss DJ, Wardrop KJ (editors).Veterinary hematology. 6th ed. Ames, Iowa, USA: John Wiley \& Sons, pp.957-967.

Zhou, B., Jia, L., Wei, S., Ding, H., Yang, J. \& Wang, H. (2020). Effects of Eimeria tenella infection on the barrier damage and microbiota diversity of chicken cecum. Poultry Science 99. https://doi.org/10.1016/j.psj.2019.10.073 